\title{
ON THE PRESENCE OF FERRITIN IN THE PERIPHERAL BLOOD OF PATIENTS WITH HEPATOCELLULAR DISEASE
}

\author{
BY KURT R. REISSMANN AND MARY R. DIETRICH
}

\author{
(From the Department of Medicine, University of Kansas School of Medicine, Kansas City, Kan.)
}

(Submitted for publication October 27, 1955; accepted February 9, 1956)

An elevated serum iron is commonly found in patients with infectious hepatitis (1-4) and evidence has been presented $(5,6)$ that acute hepatocellular necrosis, regardless of its etiology, is invariably accompanied by a rise in serum iron. A close time relationship between elevation of the serum iron and actual disintegration of liver cells has been found (6), and the hyperferremia has been attributed to a release of storage iron from the dying liver cells. As the iron is largely stored in the liver as ferritin, it was of interest to investigate whether ferritin is released into the peripheral blood of patients with acute hepatocellular disease, while it could not be demonstrated in the blood of normal individuals (7).

Mazur, Shorr, and Baez (8-10) have reported the presence of VDM, which is said to be identical with ferritin, in the peripheral blood in several conditions including hepatic cirrhosis, congestive heart failure and shock. The concentrations of this vasoactive material were so minute that their detection required the use of the mesoappendix bioassay. We were, in this study, concerned with a possible relationship between serum iron rise and the release of ferritin iron from the necrotic liver cells. The serum iron increases in such patients are in the order of one hundred to several hundred micrograms per hundred cc. of serum. If ferritin iron contributes to any significant extent to this serum iron increase, its concentration in the peripheral blood would be measurable by chemical methods after separation of the ferritin

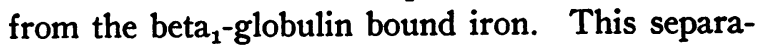
tion was accomplished by precipitation of the ferritin by means of an antiferritin immune serum. Mazur and Shorr (8) have shown that the iron content of ferritin is not altered when the protein moiety of ferritin is precipitated by means of an antibody. Ferritin iron in the serum, at concentrations we were interested in in this study, can, therefore, be measured by chemical determination of iron in the precipitate.

\section{METHODS}

Crystalline ferritin-apoferritin was prepared from human liver tissue (autopsy material) according to the method of Granick (7). The crude ferritin was recrystallized five times with $\mathrm{CdSO}_{4}$, reprecipitated at 50 per cent saturation with $\left(\mathrm{NH}_{4}\right)_{2} \mathrm{SO}_{4}$, and dialyzed against tap water for 24 hours. At that time the preparation was usually free of $\mathrm{NH}_{4}$ ions.

The antiserum was prepared according to the procedure of Mazur and Shorr (8). Rabbits were injected intravenously with aluminum precipitated human ferritin over a period of four weeks. Each animal received a total of $4.4 \mathrm{mg}$. of antigen nitrogen, and thereafter booster injections of $0.15 \mathrm{mg}$. of antigen nitrogen. The antisera were chilled, sharply centrifuged and pooled. The antiferritin titer of the antiserum was determined by adding known amounts of ferritin dissolved in human serum to one cc. of the 1:10 diluted antiserum. The mixture was incubated for one hour at $37^{\circ} \mathrm{C}$. and stored for three days at $4^{\circ} \mathrm{C}$. The tubes were then centrifuged, the precipitate washed with chilled saline, and the iron and nitrogen in the precipitate were measured. The supernatant was tested for excess of antigen or antibody.

The iron content of ferritin was measured by Scott's method (11). Other iron methods employed were the methods of Wong (12), of Barkan and Walker (13) and a modification of the latter as described below.

The ferritin determination in the blood of patients was carried out in the following manner: The blood was collected in iron free tubes and the serum was sharply centrifuged to remove all red cells. Four cc. of this serum was added to 0.3 of antiserum, to 0.3 of $1: 3$ diluted antiserum, and to $0.3 \mathrm{cc}$. of normal rabbit serum, respectively. After one hour of incubation at $37^{\circ} \mathrm{C}$. and three days' storage at $4^{\circ} \mathrm{C}$., the tubes were centrifuged. When ferritin was present, a distinct brownish precipitate could be noted in the antiserum tubes. The supernatant was decanted and that of the tube containing the undiluted antiserum was tested for excess of antigen. If ferritin was present in the supernatant, suitable serum dilutions were used in a repetition of the test until quantitative precipitation was obtained.

After washing of the precipitate with chilled iron free saline it was taken up in $3 \mathrm{cc}$. of $3 \mathrm{~N} \mathrm{HCl}$ and allowed to stand at $37^{\circ} \mathrm{C}$. for 24 hours for a complete removal of iron from the apoferritin. Thereafter one cc. of 20 per cent trichloracetic acid was added under constant shaking. After one hour the tubes were centrifuged, and to $2 \mathrm{cc}$. of the clear supernatant fluid $1.5 \mathrm{cc}$. of saturated sodium acetate, $0.3 \mathrm{cc}$. of 1 per cent ascorbic acid and $0.5 \mathrm{cc}$. of 
0.1 per cent o-phenanthroline were added. The optical density was measured at 5,150 A.U. in a Beckman spectrophotometer.

\section{RESULTS}

\section{A) Comments on the procedures}

The yield of highly purified ferritin-apoferritin from human liver tissue was small. $45.8 \mathrm{mg}$. apoferritin nitrogen or approximately $413 \mathrm{mg}$. of ferritin were obtained from a total of $14.7 \mathrm{Kg}$. of human liver tissue. The $\mathrm{Fe}: \mathrm{N}$ ratio in the pooled preparation, which was obtained from 34 different human liver specimens, was $1.64: 1$.

Mazur and Shorr (8) have shown that the ironapoferritin complex is not altered, as far as its iron content is concerned, when horse spleen ferritin is precipitated by means of an immune serum. Table I indicates that the same holds for human ferritin. A quantitative precipitation can only be expected in the equivalent zone, although moderate antibody excess did not affect the test materially, as seen in Table I. For the ferritin determination in patients' serum, ratios of patients' serum to antiserum were, therefore, used routinely which provided a quantitative precipitation of ferritin in serum concentrations equivalent to a ferritin iron concentration of from 25 to $400 \mu \mathrm{g}$. per cent. When higher ferritin concentrations were encountered, the test was repeated with suitable serum dilutions.

No attempts were made to measure ferritin iron concentrations in patients' serum below $0.2 \mu \mathrm{g}$. per cc. The routine determination of such small

TABLE I

Precipitation of ferritin iron by antiferritin serum

(One cc. of $1: 10$ diluted antiserum plus 2 cc. of human ferritin in saline or in human serum)

\begin{tabular}{|c|c|c|c|c|}
\hline \multicolumn{2}{|c|}{ In saline } & \multicolumn{2}{|c|}{ In human serum } & \\
\hline $\begin{array}{c}\text { Ferritin } \\
\text { iron } \\
\text { added }\end{array}$ & $\begin{array}{c}\text { Iron } \\
\text { found } \\
\text { in ppt. }\end{array}$ & $\begin{array}{c}\text { Ferritin } \\
\text { iron } \\
\text { added }\end{array}$ & $\begin{array}{c}\text { Iron } \\
\text { found } \\
\text { in ppt. }\end{array}$ & \\
\hline $\begin{array}{l}\text { m8. } \\
0.54 \\
1.08\end{array}$ & $\begin{array}{l}\text { M.8. } \\
0.64 \\
1.24\end{array}$ & $\begin{array}{l}\text { Mg. } \\
0.54 \\
1.08\end{array}$ & $\begin{array}{c}\text { Mg. } \\
0.52 \\
0.96\end{array}$ & $\begin{array}{l}\text { Antibody } \\
\text { excess }\end{array}$ \\
\hline $\begin{array}{l}3.24 \\
6.48\end{array}$ & $\begin{array}{l}3.10 \\
6.30\end{array}$ & $\begin{array}{l}2.16 \\
4.32\end{array}$ & $\left.\begin{array}{l}2.08 \\
4.38\end{array}\right)$ & $\underbrace{\text { Equivalent }}_{\text {zone }}$ \\
\hline $\begin{array}{r}9.72 \\
12.96 \\
19.44 \\
25.92\end{array}$ & $\begin{array}{l}5.88 \\
4.92 \\
3.08 \\
2.52\end{array}$ & $\begin{array}{r}8.64 \\
17.28 \\
34.56\end{array}$ & $\begin{array}{l}7.34 \\
4.88 \\
0.12\end{array}$ & $\left\{\begin{array}{r}\text { Antigen } \\
\text { excess }\end{array}\right.$ \\
\hline
\end{tabular}

TABLE II

Effect of serum iron level (non-ferritin) upon ferritin iron recovery in precipitate

(2.14 $\mu \mathrm{g}$. per cent ferritin iron was added to human serum containing 72, 272, 572 and 1,572 $\mu \mathrm{g}$. per cent non-ferritin iron. After precipitation with antiferritin serum the following amounts of iron were found in the precipitate)

\begin{tabular}{cccccc}
\hline \hline & \multicolumn{2}{c}{ With antiserum } & & \multicolumn{2}{c}{ With control serum } \\
\cline { 2 - 3 } \cline { 6 - 6 } $\begin{array}{c}\text { Serum iron } \\
\text { (Non-ferritin) }\end{array}$ & Found & Expected & & Found & Expected \\
\hline$\mu g . \%$ & & & & 0 & 0 \\
72 & 2.07 & 2.14 & & 0 & 0 \\
272 & 2.01 & 2.14 & & 0.18 & 0 \\
572 & 2.42 & 2.14 & & 0.94 & 0 \\
1572 & 3.08 & 2.14 & & & \\
\hline
\end{tabular}

amounts of iron in the precipitate is rather inaccurate and subject to contamination, and it was not the aim of this study to detect minimal ferritin concentrations in the patients' serum. The term "no ferritin," used in the presentation of the results, thus refers to the absence of ferritin, above the concentration of $20 \mu \mathrm{g}$. per cent ferritin iron, and likewise the term ferritinemia, as used in this paper, indicates the presence of ferritin above this concentration.

The validity of the ferritin determination in serum by measuring the iron content of the precipitate depends furthermore upon the specificity of the antiserum, i.e., the antiserum must not, directly or indirectly, precipitate other iron containing compounds of the serum, viz., beta -globulin $_{1}$ iron, iron in excess of the iron binding capacity of the serum or hemoglobin iron. When hemoglobin was added to ferritin containing serum, the iron recovery in the precipitate was not affected by hemoglobin concentrations high enough to produce a distinct coloring of the serum (approximately $0.8 \mathrm{mg}$. per cent hemoglobin $\mathrm{Fe}$ ). The effect of non-ferritin serum iron, within or in ex-

TABLE III

Absence of ferritin in the blood of patients with elevated serum iron not caused by liver disease

\begin{tabular}{|c|c|c|c|}
\hline $\begin{array}{c}\text { Number } \\
\text { of } \\
\text { patients }\end{array}$ & Diagnosis & $\underset{\text { iron }}{\text { Serum }}$ & $\begin{array}{c}\text { Ferritin } \\
\text { iron }\end{array}$ \\
\hline $\begin{array}{l}6 \\
6 \\
5 \\
3 \\
2 \\
6 \\
1\end{array}$ & $\begin{array}{l}\text { Pernicious anemia } \\
\text { Hypoplastic anemia } \\
\text { Congenit. aplast. anemia } \\
\text { Hemolytic anemia } \\
\text { Primary polycythemia } \\
\text { After blood transfusions } \\
\text { Ca. prostate, fibrinolysis } \\
\text { and massive ecchymoses }\end{array}$ & $\begin{array}{c}\mu g . \% \\
179-249 \\
192-258 \\
238-383 \\
96-208 \\
233-245 \\
126-232 \\
249\end{array}$ & $\begin{array}{l}\text { None: } \\
\text { None } \\
\text { None } \\
\text { None } \\
\text { None } \\
\text { None } \\
\text { None }\end{array}$ \\
\hline
\end{tabular}


TABLE IV

Serum iron, ferritin iron and hepatogram in patients with acute hepatocellular disease

\begin{tabular}{|c|c|c|c|c|c|c|c|c|c|c|c|c|}
\hline \multirow[b]{2}{*}{ Diagnosis } & \multirow{2}{*}{$\begin{array}{l}\text { Days } \\
\text { after } \\
\text { onset }\end{array}$} & \multirow{2}{*}{$\begin{array}{c}\text { Serum } \\
\text { iron }\end{array}$} & \multirow{2}{*}{$\begin{array}{c}\text { Ferritin } \\
\text { iron }\end{array}$} & \multicolumn{8}{|c|}{ Hepatogram* } & \multirow[b]{2}{*}{ NPN } \\
\hline & & & & T.B. & A.P. & c.c. & T.T. & Prot. & Chol. & C.E. & BSP & \\
\hline $\begin{array}{l}\text { Acute yellow } \\
\text { atrophy }\end{array}$ & $\begin{array}{l}3 \\
4\end{array}$ & $\begin{array}{l}\mu \mathrm{g} . \% \\
1,426 \\
1,176\end{array}$ & $\begin{array}{c}\mu 8 . \% \\
863 \\
571\end{array}$ & 73 & 3 & 2 & 13 & 24 & 120 & 12 & & $\begin{array}{c}\text { mg. \% } \\
103\end{array}$ \\
\hline $\begin{array}{r}\mathrm{CCl}_{\text {, inhalat. }} \\
\text { (nephrosis) }\end{array}$ & $\begin{array}{r}5 \\
30\end{array}$ & $\begin{array}{l}225 \\
150\end{array}$ & $\begin{array}{r}31 \\
0\end{array}$ & $\begin{array}{l}3 \\
7\end{array}$ & $\begin{array}{l}2 \\
3\end{array}$ & $\begin{array}{l}2 \\
1\end{array}$ & $\begin{array}{l}3 \\
2\end{array}$ & $\begin{array}{l}60 \\
95\end{array}$ & & & $\begin{array}{r}25 \\
0\end{array}$ & $\begin{array}{r}315 \\
37\end{array}$ \\
\hline $\begin{array}{c}\text { Thorazine } \\
\text { jaundice }\end{array}$ & $\begin{array}{r}6 \\
18\end{array}$ & $\begin{array}{l}141 \\
137\end{array}$ & $\begin{array}{l}0 \\
0\end{array}$ & $\begin{array}{r}11 \\
8\end{array}$ & $\begin{array}{l}36 \\
28\end{array}$ & $\begin{array}{l}2 \\
2\end{array}$ & $\begin{array}{l}7 \\
6\end{array}$ & $\begin{array}{l}60 \\
74\end{array}$ & $\begin{array}{l}485 \\
362\end{array}$ & $\begin{array}{l}12 \\
36\end{array}$ & $\begin{array}{l}50 \\
35\end{array}$ & \\
\hline $\begin{array}{l}\text { Viral hepatitis } \\
\text { severe }\end{array}$ & $\begin{array}{r}3 \\
6 \\
10 \\
19\end{array}$ & $\begin{array}{l}336 \\
289 \\
241 \\
165\end{array}$ & $\begin{array}{r}69 \\
38 \\
0 \\
0\end{array}$ & $\begin{array}{c}13 \\
20 \\
6 \\
2.3\end{array}$ & $\begin{array}{l}3 \\
2\end{array}$ & $\begin{array}{l}4 \\
1\end{array}$ & $\begin{array}{l}28 \\
20\end{array}$ & $\begin{array}{l}25 \\
85\end{array}$ & $\begin{array}{l}218 \\
316\end{array}$ & $\begin{array}{l}50 \\
67\end{array}$ & & \\
\hline $\begin{array}{l}\text { Viral hepatitis } \\
\text { severe }\end{array}$ & $\begin{array}{r}3 \\
11 \\
21 \\
29\end{array}$ & $\begin{array}{l}215 \\
260 \\
298 \\
186\end{array}$ & $\begin{array}{r}30 \\
29 \\
0 \\
0\end{array}$ & $\begin{array}{r}15 \\
32 \\
23 \\
6\end{array}$ & $\begin{array}{l}5 \\
4 \\
3 \\
4\end{array}$ & $\begin{array}{l}3 \\
4 \\
4 \\
3\end{array}$ & $\begin{array}{l}19 \\
27 \\
21 \\
13\end{array}$ & $\begin{array}{l}80 \\
60 \\
60 \\
80\end{array}$ & $\begin{array}{l}188 \\
164 \\
189 \\
211\end{array}$ & $\begin{array}{l}41 \\
27 \\
45 \\
44\end{array}$ & & \\
\hline Viral hepatitis & $\begin{array}{r}4 \\
15 \\
25\end{array}$ & $\begin{array}{l}266 \\
228 \\
168\end{array}$ & $\begin{array}{r}74 \\
0 \\
0\end{array}$ & $\begin{array}{l}22 \\
35 \\
13\end{array}$ & & $\begin{array}{l}4 \\
4 \\
4\end{array}$ & $\begin{array}{l}26 \\
38 \\
14\end{array}$ & $\begin{array}{l}26 \\
76\end{array}$ & $\begin{array}{l}136 \\
344\end{array}$ & $\begin{array}{l}38 \\
51\end{array}$ & & \\
\hline Viral hepatitis & $\begin{array}{r}6 \\
10\end{array}$ & $\begin{array}{l}413 \\
313\end{array}$ & $\begin{array}{r}35 \\
0\end{array}$ & $\begin{array}{l}9 \\
7\end{array}$ & $\begin{array}{l}2 \\
2\end{array}$ & $\begin{array}{l}3 \\
\mathbf{3}\end{array}$ & $\begin{array}{l}15 \\
13\end{array}$ & $\begin{array}{l}76 \\
75\end{array}$ & $\begin{array}{l}224 \\
200\end{array}$ & $\begin{array}{l}59 \\
50\end{array}$ & $\begin{array}{l}24 \\
15\end{array}$ & \\
\hline Viral hepatitis & $\begin{array}{r}9 \\
18\end{array}$ & $\begin{array}{l}324 \\
331\end{array}$ & $\begin{array}{l}64 \\
29\end{array}$ & $\begin{array}{r}12 \\
6\end{array}$ & $\begin{array}{l}3 \\
3\end{array}$ & $\begin{array}{l}4 \\
3\end{array}$ & $\begin{array}{r}10 \\
9\end{array}$ & $\begin{array}{r}80 \\
100\end{array}$ & $\begin{array}{l}130 \\
120\end{array}$ & $\begin{array}{l}54 \\
46\end{array}$ & 35 & \\
\hline Viral hepatitis & $\begin{array}{r}2 \\
10 \\
16\end{array}$ & $\begin{array}{l}272 \\
286 \\
236\end{array}$ & $\begin{array}{r}86 \\
46 \\
0\end{array}$ & $\begin{array}{l}15 \\
14 \\
12\end{array}$ & $\begin{array}{l}4 \\
7 \\
5\end{array}$ & $\begin{array}{l}4 \\
4 \\
4\end{array}$ & $\begin{array}{l}20 \\
20 \\
24\end{array}$ & & 100 & 40 & & \\
\hline Viral hepatitis & $\begin{array}{r}4 \\
17\end{array}$ & $\begin{array}{l}313 \\
185\end{array}$ & $\begin{array}{r}35 \\
0\end{array}$ & $\begin{array}{r}19 \\
4\end{array}$ & $\begin{array}{r}11 \\
4\end{array}$ & $\begin{array}{l}3 \\
2\end{array}$ & $\begin{array}{r}14 \\
6\end{array}$ & & $\begin{array}{l}250 \\
200\end{array}$ & $\begin{array}{l}30 \\
60\end{array}$ & & \\
\hline Viral hepatitis & $\begin{array}{r}2 \\
5 \\
11 \\
18\end{array}$ & $\begin{array}{l}241 \\
312 \\
333 \\
211\end{array}$ & $\begin{array}{r}22 \\
46 \\
10 \\
0\end{array}$ & $\begin{array}{r}4 \\
28 \\
26 \\
14\end{array}$ & 3 & 1 & 16 & 70 & $\begin{array}{l}250 \\
260\end{array}$ & $\begin{array}{l}50 \\
55\end{array}$ & & \\
\hline
\end{tabular}

* T. B. = total serum bilirubin in mg. per cent; A. P. = alkaline phosphatase in mMol ; C. C. = cephalin-cholesterol flocculation in units; T. T. = thymol turbidity in units; Chol. = serum cholesterol in mg. per cent; C. E. = per cent cholesterol esters; Prot. $=$ prothrombin in per cent of normal; BSP $=$ Bromsulfalein, 2 mg. per kilo, in per cent retained after $45 \mathrm{~min}$.

cess of the iron binding capacity, upon the recovery of ferritin iron in the precipitate was ascertained in experiments illustrated in Table II. The results show that slight amounts of non-ferritin iron were found in the precipitate when the serum iron was greatly in excess of the iron binding capacity of the serum. This error could however easily be detected in the control tubes.

In two instances (Table $V$ ), the total serum iron (i.e., beta ${ }_{1}$-globulin iron plus ferritin iron) as measured by Barkan's method was found to be lower than the ferritin iron concentration alone, as derived from the iron determination in the precipitate. The explanation of this discrepancy was found in the relatively high stability of the iron-apoferritin complex against removal of the iron in a moderately acid medium. While the $\mathbf{0 . 3}$ $\mathrm{N} \mathrm{HCl}$, which is added to serum in Barkan's serum iron method, breaks up the beta ${ }_{1}$-globulin iron complex quantitatively, only from 60 to 80 per cent of ferritin iron, which had been added to the serum, was removed from the apoferritin at this $\mathrm{pH}$. The term serum iron, used in Tables IV and $\mathrm{V}$ to designate the iron as measured by Barkan's method, thus comprises the beta ${ }_{1}$-globulin iron plus this fraction of the ferritin iron. 


\section{B) Ferritin iron in the serum of patients}

1. Patients with normal serum iron levels and without liver disease: On repeated examination, no ferritin iron was found in the serum of 31 individuals of this group, which included patients with hypertension, diabetes, peptic ulcers, leukemia and healthy subjects.

2. Patients with elevated serum iron levels and without liver disease: No ferritin was found in 29 patients of this group with conditions listed in Table III. Three of the patients with aplastic anemia showed advanced hemosiderosis on liver biopsy.
3. Patients with acute hepatocellular disease (Table IV): Extraordinarily high serum iron values and considerable amounts of circulating ferritin were found in a patient with acute yellow atrophy. This patient was a 32-year-old negro alcoholic who entered the hospital in a semicomatose condition on the third day of an acute illness and who died 48 hours later. At autopsy an almost completely necrotic liver was found, and the renal tubules showed a considerable degree of albuminuric degeneration. The etiology of the disease could not be determined, but intoxication with some hepatotoxic solvent was suspected.

Small amounts of ferritin iron were found in

TABLE V

Serum iron, ferritin iron and hepatogram in granulomatous or neoplastic liver disease

\begin{tabular}{|c|c|c|c|c|c|c|c|c|c|c|c|}
\hline \multirow[b]{2}{*}{ Diagnosis } & \multirow[b]{2}{*}{ Date } & \multirow{2}{*}{$\underset{\text { Serum }}{\text { iron }}$} & \multirow{2}{*}{$\begin{array}{c}\text { Ferritin } \\
\text { iron }\end{array}$} & \multicolumn{7}{|c|}{ Hepatogram* } & \\
\hline & & & & T.B. & A.P. & C.C. & T.T. & Prot. & Chol. & C.E. & \\
\hline $\begin{array}{c}\text { Hodgkin } \\
\text { (J. B.) }\end{array}$ & $\begin{array}{l}7-3 \\
7-8 \\
7-10\end{array}$ & $\begin{array}{l}\text { Mg. \% } \\
216 \\
464 \\
446\end{array}$ & $\begin{array}{l}\mu 8 . \% \\
185 \\
312 \\
415\end{array}$ & $\begin{array}{l}35 \\
33\end{array}$ & $\begin{array}{l}30 \\
26\end{array}$ & 1 & 5 & 40 & 336 & 22 & Died 7-10 \\
\hline $\begin{array}{l}\text { Hodgkin } \\
\text { (W. F.) }\end{array}$ & $\begin{array}{l}6-30 \\
7-1 \\
7-3 \\
7-8 \\
7-13 \\
7-16\end{array}$ & $\begin{array}{l}566 \\
394 \\
234 \\
106 \\
251 \\
568\end{array}$ & $\begin{array}{r}583 \\
362 \\
41 \\
0 \\
236 \\
686\end{array}$ & $\begin{array}{l}12 \\
37 \\
21 \\
18 \\
31 \\
34\end{array}$ & 6 & 2 & 2 & 45 & 248 & 39 & $\begin{array}{l}\text { X-ray therapy } \\
\text { including liver } \\
\text { discont. 6-30 } \\
\text { Died 7-21 }\end{array}$ \\
\hline $\begin{array}{l}\text { Hodgkin } \\
\text { (C. G.) }\end{array}$ & $\begin{array}{l}1-6 \\
1-11 \\
1-15 \\
1-18\end{array}$ & $\begin{array}{r}80 \\
260 \\
286 \\
378\end{array}$ & $\begin{array}{r}0 \\
32 \\
197 \\
280\end{array}$ & $\begin{array}{r}9 \\
20\end{array}$ & $\begin{array}{l}7 \\
8\end{array}$ & $\begin{array}{l}1 \\
2\end{array}$ & $\begin{array}{l}4 \\
0\end{array}$ & $\begin{array}{l}40 \\
30\end{array}$ & $\begin{array}{l}150 \\
143\end{array}$ & $\begin{array}{l}10 \\
10\end{array}$ & $\begin{array}{l}\text { TEM on 1-7 } \\
\text { to } 11 \\
\text { Died } 1-21\end{array}$ \\
\hline $\begin{array}{l}\text { Hodgkin } \\
\text { (C. S.) }\end{array}$ & $\begin{array}{r}8-30 \\
10-14 \\
10-21\end{array}$ & $\begin{array}{r}87 \\
152 \\
225\end{array}$ & $\begin{array}{r}0 \\
133 \\
87\end{array}$ & $\begin{array}{l}0.5 \\
1\end{array}$ & $\begin{array}{l}2 \\
4\end{array}$ & $\begin{array}{l}0 \\
0\end{array}$ & $\begin{array}{l}0 \\
0\end{array}$ & $\begin{array}{l}90 \\
70\end{array}$ & $\begin{array}{l}190 \\
260\end{array}$ & $\begin{array}{l}55 \\
59\end{array}$ & $\begin{array}{l}\text { TEM on } 10-15 \\
\text { and } 10-16 \\
\text { died } 2 \text { mnths. } \\
\text { later }\end{array}$ \\
\hline $\begin{array}{c}\text { Hodgkin } \\
\text { (S. C.) }\end{array}$ & $\begin{array}{l}9-20 \\
10-1 \\
10-4 \\
11-10\end{array}$ & $\begin{array}{r}55 \\
141 \\
195 \\
309\end{array}$ & $\begin{array}{r}10 \\
76 \\
112 \\
114\end{array}$ & $\begin{array}{l}0.3 \\
2 \\
14 \\
10\end{array}$ & $\begin{array}{r}2 \\
14 \\
12 \\
31\end{array}$ & $\begin{array}{l}0 \\
0 \\
0 \\
2\end{array}$ & $\begin{array}{l}0 \\
0 \\
0 \\
1\end{array}$ & $\begin{array}{l}68 \\
60 \\
47\end{array}$ & $\begin{array}{l}165 \\
180 \\
140 \\
140\end{array}$ & $\begin{array}{l}50 \\
46 \\
11 \\
14\end{array}$ & Died 11-25 \\
\hline $\begin{array}{r}\text { Hodgkin } \\
\text { (C. E.) }\end{array}$ & $\begin{array}{l}3-9 \\
4-18 \\
4-25 \\
4-27 \\
5-4 \\
5-11\end{array}$ & $\begin{array}{r}56 \\
211 \\
431 \\
496 \\
136 \\
106\end{array}$ & $\begin{array}{r}0 \\
36 \\
96 \\
81 \\
23 \\
65\end{array}$ & $\begin{array}{l}0.3 \\
1.3 \\
14 \\
47 \\
15 \\
18\end{array}$ & $\begin{array}{r}2 \\
8 \\
9 \\
12 \\
14 \\
8\end{array}$ & $\begin{array}{l}1 \\
1 \\
1 \\
2 \\
2 \\
1\end{array}$ & $\begin{array}{l}2 \\
3 \\
2 \\
3 \\
3 \\
1\end{array}$ & $\begin{array}{l}80 \\
68 \\
60 \\
60 \\
37\end{array}$ & $\begin{array}{l}204 \\
217 \\
190 \\
260 \\
220 \\
155\end{array}$ & $\begin{array}{l}66 \\
46 \\
19 \\
16 \\
23 \\
16\end{array}$ & $\begin{array}{l}\text { TEM on 4-20 } \\
\text { and } 21 \\
\text { Died 11-5 }\end{array}$ \\
\hline Sarcoid & $\begin{array}{l}3-2 \\
5-4\end{array}$ & $\begin{array}{r}100 \\
70\end{array}$ & $\begin{array}{l}\mathbf{0} \\
\mathbf{0}\end{array}$ & $\begin{array}{l}0.7 \\
0.2\end{array}$ & $\begin{array}{r}10 \\
4\end{array}$ & $\begin{array}{l}3 \\
1\end{array}$ & $\begin{array}{l}4 \\
1\end{array}$ & $\begin{array}{r}90 \\
100\end{array}$ & $\begin{array}{l}125 \\
165\end{array}$ & $\begin{array}{l}57 \\
67\end{array}$ & \\
\hline Sarcoid & $8-6$ & 58 & 0 & 0.3 & 2 & 0 & 1 & 80 & 165 & 62 & \\
\hline Ca metast. & & 45 & $\mathbf{0}$ & 0.9 & 2 & 2 & 5 & 100 & 140 & 59 & \\
\hline Ca metast. & & 30 & 0 & 1.5 & 13 & 1 & 2 & 90 & 170 & 53 & \\
\hline Ca metast. & & 64 & 0 & 7 & 22 & 1 & 2 & 90 & 125 & 50 & \\
\hline
\end{tabular}

\footnotetext{
* Symbols same as in Table IV.
} 
a moderately jaundiced patient with carbon tetrachloride intoxication. The liver biopsy showed in this patient a moderate degree of hepatocellular involvement and the intoxication was mainly manifested in a severe nephrosis. No ferritin was found in a patient with severe jaundice due to thorazine medication. The liver biopsy showed in this patient very little hepatocellular damage, but a marked bile-stasis in smaller bile ducts.

As seen in Table IV, ferritin was found in the peripheral blood of eight patients with viral hepatitis during the first ten days of the disease. Thereafter the ferritin disappeared from circulation while the serum iron remained elevated. No correlation was detected between the presence of ferritin and liver function tests listed in Table IV. In nine other patients with viral hepatitis, ferritin was not found at any time during the disease, although the serum iron elevation in these patients was similar to those listed in Table IV.

Frequent observations on pulse rate, blood pressure, EKG and urinary output were made in these two groups of viral hepatitis patients with or without ferritinemia. Neither from these measurements nor from general clinical observation was any circulatory effect noted that could be attributed in these patients to the presence of ferritin in the circulating blood.

4. Patients with chronic hepatic disease: No ferritin was found in the blood of eight patients with quiescent portal cirrhosis who had various degrees of hepatic dysfunction and portal hypertension. The serum iron in these patients was in the low range of from 43 to $132 \mu \mathrm{g}$. per cent. No ferritin was found in six patients with portal cirrhosis who presented on liver biopsy and by elevated serum iron (levels ranging from 193 to 232 $\mu \mathrm{g}$. per cent) evidence of some active hepatocellular degeneration. In one patient with advanced portal cirrhosis and serum iron levels of 197 and $218 \mu \mathrm{g}$. per cent, 20 and $36 \mu \mathrm{g}$. per cent ferritin iron, respectively, was found in the peripheral blood. The patient died in hepatic coma and at autopsy areas of fresh hepatocellular necrosis were seen. No ferritin was found in two patients with biliary cirrhosis (serum iron 54 and $188 \mu \mathrm{g}$. per cent), in one patient with amebic liver abscess (serum iron $35 \mu \mathrm{g}$. per cent) and in one patient with hemochromatosis (serum iron between 250 and $320 \mu \mathrm{g}$. per cent).
5. Patients with granulomatous or neoplastic hepatic disease (Table $V$ ): The most persistent ferritinemia was found in six out of six patients with Hodgkin's disease involving the liver. It will be noted that in these patients the ferritin iron accounts for most if not all of the observed hyperferremia. Patient J. B. (Table V) had jaundice of two years' duration, and at the day of his death $415 \mu \mathrm{g}$. per cent ferritin iron was found in his blood and a serum iron of $446 \mu \mathrm{g}$. per cent. The liver showed extensive necroses in centrolobular areas, hemosiderin in these areas and in Kupffer cells, and a slight increase in the portal fibrous tissue. Patient W. F. had received $x$-ray therapy, including the liver, and $583 \mu \mathrm{g}$. per cent ferritin iron was found on the day the therapy was discontinued. Ferritin and serum iron declined on subsequent examinations but rose again to $686 \mu \mathrm{g}$. per cent ferritin iron before death. The liver presented an almost identical picture as in the aforementioned patient. In patient C. G. the jaundice became more marked and the appearance of ferritin was noted subsequent to nitrogen mustard therapy. The patient succumbed several days later, and massive necroses were found in the liver which showed a diffuse periportal infiltration with lymphogranulomatous tissue. In patient C. E. an increase of the already elevated serum iron and ferritin levels will be noted following nitrogen mustard therapy. Prior to his death the serum iron was only $106 \mu \mathrm{g}$. per cent while $65 \mu \mathrm{g}$. per cent ferritin iron were found in the serum. The liver showed a moderate degree of fresh hepatocellular necrosis. In patient $C$. S. significant amounts of ferritin were found, although the patient did not show at that time any evidence of hepatic involvement. $\mathrm{He}$ was discharged, became jaundiced four weeks later and died eight weeks after his discharge. No autopsy was obtained.

In contrast to these patients with Hodgkin's disease of the liver who all showed a pronounced ferritinemia, no ferritin (or elevation of serum iron) was found in two patients with sarcoidosis of the liver, although both these patients had extreme enlargement of liver and spleen. Likewise no ferritin was found in three cases of carcinomatosis of the liver.

In view of the marked ferritinemia found in patients with Hodgkin's disease of the liver, 14 
patients with proven Hodgkin's disease, but with no evidence of liver involvement were studied over a period of more than one year. In all of these patients low serum iron values were found, ranging from 26 to $128 \mu \mathrm{g}$. per cent (mean $66 \mu \mathrm{g}$. per cent), and in no instance was ferritin present in the serum. Six of these patients were autopsied and the liver was found free of granulomatous infiltration. Three of these patients had received nitrogen mustard therapy, but no ferritin or significant serum iron changes were found during or after its administration.

\section{C) The disappearance rate of ferritin from the circulation}

Considering the release of ferritin from the dying liver cells as the source of the ferritin found in the blood of patients with acute hepatocellular necrosis, it was of interest to obtain information on the disappearance rate of ferritin from the circulation. In view of the possible viral contamination of the ferritin prepared from a large number of human livers, no experiments were carried out in human patients. The human ferritin was, therefore, injected intravenously in dogs and the ferritin level in the blood was followed, although it was realized that these experiments would not necessarily indicate the disappearance rate of autogenous ferritin in humans. Following injection of ferritin, the ferritin was quantitatively precipitated in the serum samples and the iron content in the supernatant serum is referred to as beta ${ }_{1}$ globulin bound iron in Figure 1.

As seen in Figure 1, there was in both experiments a rather fast disappearance of ferritin from the circulation during the first hour. Thereafter the disappearance rate amounted to about 50 per cent in twenty-four hours. No significant changes

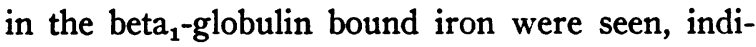
cating that no splitting of the iron from the ferritin molecule and subsequent binding of the free

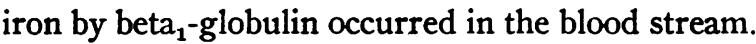

In both experiments, blood pressure (recorded by strain gauge in femoral artery) and EKG were recorded continuously before, during and for a period of 60 minutes after the injections of ferritin. No changes were found.

\section{DISCUSSION}

In all patients, where ferritin was found in the peripheral blood, acute hepatocellular necrosis was either demonstrated anatomically, or could

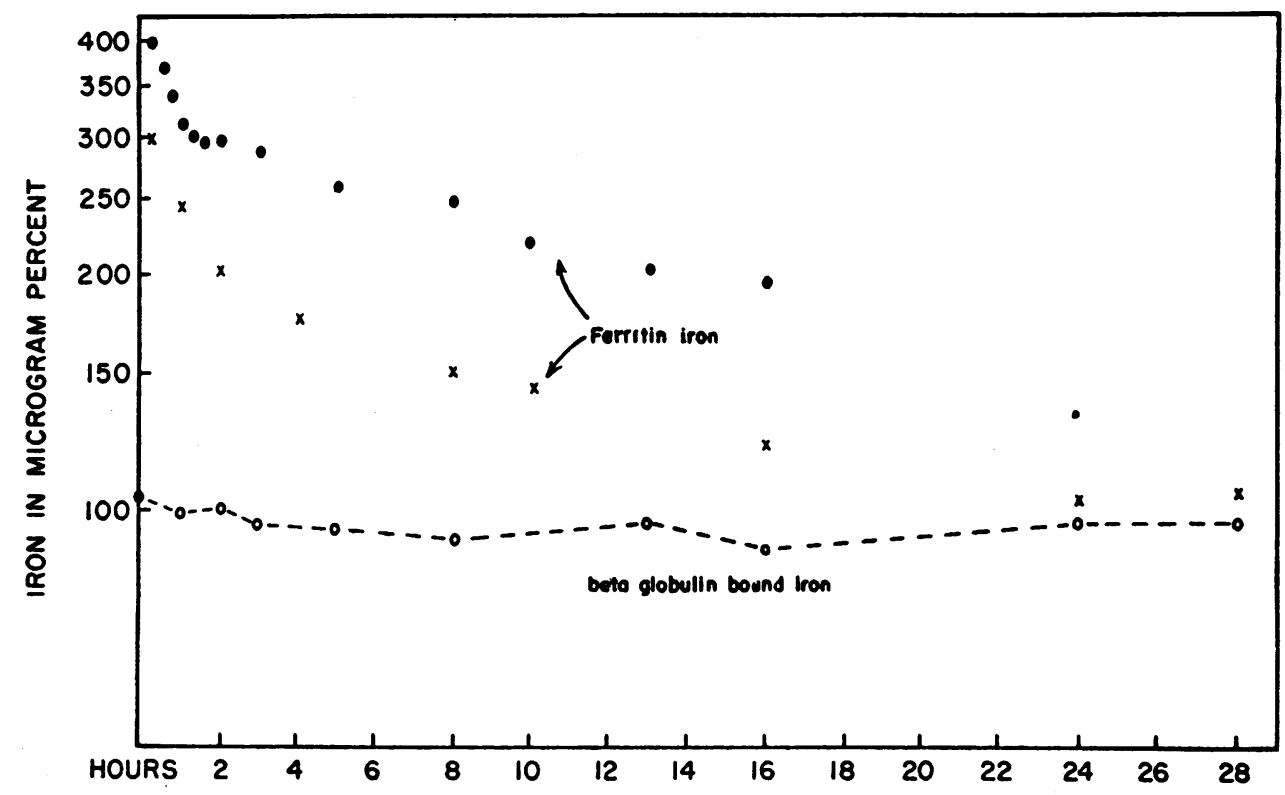

Fig. 1. Ferritin Iron and Beta - Globulin Iron in Serum of Dogs after I.V. Injection of HuMaN FerRitin

- ferritin iron, $\bigcirc-\bigcirc$ beta $_{1}-$ globulin iron in dog 1 (11.3 $\mathrm{Kg}$.) after injection of ferritin containing $2.013 \mathrm{mg}$. Fe., $X \times$ ferritin iron in $\operatorname{dog} 2(12.4 \mathrm{Kg}$.) after injection of ferritin containing $1.911 \mathrm{mg}$. Fe. 
be assumed to be present, as in some cases of hepatitis where no biopsy was performed. This relationship was especially striking in the patient with rapidly fatal yellow atrophy. An extraordinarily high ferritin iron concentration of $863 \mu \mathrm{g}$. per cent was measured in this patient, and at autopsy 24 hours later the liver was found to be nearly completely necrotic.

However, less than one-half of the patients with viral hepatitis showed measurable amounts of ferritin in the blood, although by general clinical appearance and liver function tests, the disease was no less severe in patients who did not have any ferritin in the blood. In some of these patients, serum iron and serum ferritin were followed daily beginning at the first day of jaundice. While the beta ${ }_{1}$-globulin iron became greatly elevated in the course of the disease, no ferritin was found at any time, indicating that the hyperferremia commonly seen in hepatocellular necrosis is not necessarily related to a release of ferritin in concentrations that can be detected by the precipitation method used in this study.

Lack of functioning liver cells, e.g., in patients with advanced cirrhosis, was not accompanied by

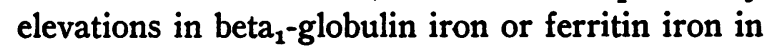
the plasma. It seems, therefore, that elevation in beta ${ }_{1}$-globulin iron and appearance of ferritin in the blood depend on acute injury of liver cells, and that the damaged liver cell may either release ferritin or iron. It is possible that during rapid cell destruction the ferritin leaves the cell as such, while in a slowly degenerating cell the ferritin iron is released by a mechanism described by Mazur, Baez, and Shorr (14). These authors found in dogs during drastic hemorrhagic hypotension a progressive transfer of ferrous iron from sulfhydryl-ferrous-ferritin in the hypoxic liver to the plasma, where it combined with the beta ${ }_{1}$-globulin.

No entirely satisfactory explanation can be offered of the markedly high ferritin concentrations found in all patients with Hodgkin's disease of the liver. Acute hepatocellular necrosis was found at autopsy or biopsy in all of these cases, but the impression was gained that the ferritinemia in these patients was unusually high and persistent compared to the extent of hepatocellular necrosis. Furthermore the ferritin iron accounted for most or all of the elevation in serum iron, i.e., the beta $a_{1}$ globulin iron was not significantly elevated. This is in contrast to the patients with viral or toxic

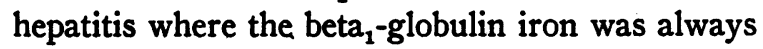
considerably elevated in addition to the hyperferremia produced by the ferritin iron. Sarcoid or cancer metastases of the liver did not produce ferritinemia and likewise not Hodgkin's disease per se, i.e., without liver involvement. Nitrogen mustard or roentgen therapy was accompanied or followed by an increase in circulating ferritin only in those patients who had lymphogranulomatous infiltration of the liver. Haley, Andem, Riley, and Williams $(15,16)$ found significant concentrations of vasoactive ferritin in the blood of animals following irradiation with lethal or near lethal doses, but it is likely that the mechanism of this ferritin release differed from that seen after therapeutic doses in the patients with Hodgkin's disease.

No obvious pathophysiological effects of the circulating ferritin were observed. In the two experiments where considerable amounts of purified human ferritin were injected into dogs, no changes in EKG or arterial pressure were noted, the latter finding being in accordance with earlier observations of Baez, Mazur, and Shorr (17). In the case of patients, where ferritin was found in the peripheral circulation, it is difficult to distinguish in an individual patient between the cardiovascular effect of the disease as such and the possible effect of circulating ferritin. On the whole, however, no relationship between blood pressure, pulse rate or urinary output and the concentration of circulating ferritin could be established. The ferritinemia in these patients appeared to be merely a symptom of hepatocellular necrosis rather than to have an obnoxious effect per se.

From these findings, no inferences can be drawn as to the vasoactive properties of ferritin, described by Mazur, Shorr, and Baez $(8,9,17)$. These workers have shown that ferritin can exist in two forms in the body, a biologically inert form which is present in the aerobic liver, and a vasoactive ferritin converted from the former by anaerobic reduction. The reduced ferritin exerts vasoactive effects in concentrations much smaller than those that can be ascertained by the microprecipitine test, and furthermore, this test cannot differentiate between the two forms of ferritin. Therefore, the data presented here do not provide information on the presence or absence of the vasoactive form of ferritin. The demonstration of the latter in the 
plasma requires the mesoappendix assay and was beyond the scope of this study, which was primarily concerned with the role of ferritin release in relation to hyperferremia in hepatocellular damage. From the absence of any noticeable vasoactive or antidiuretic effects of the circulating ferritin encountered in this study, it would appear that this ferritin was either released in its inactive form or was inactivated rapidly in the blood stream. The latter possibility would be in agreement with observations of Baez, Mazur, and Shorr (17), who found, following injection of ferritin into dogs, a rapid fall of the titer of biologically active ferritin and attributed this inactivation to an oxidation to the inert disulfide-ferric form.

\section{SUMMARY}

Repeated ferritin-iron determinations by means of an immuno-chemical method were carried out on the blood of 112 human patients.

Circulating ferritin, above the limit of accuracy of the method, was found only in patients with acute hepatocellular disease. These included one case of acute yellow atrophy, where $863 \mu$ g. per cent of ferritin iron were found, and eight patients with infectious hepatitis. In nine other patients with infectious hepatitis no ferritin could be de-

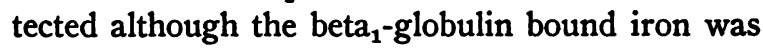
markedly elevated. Lack of functioning liver cells in patients with advanced hepatic cirrhosis did not produce ferritinemia. Likewise no ferritin was found in 29 patients with elevated serum iron levels caused by other than hepatocellular disease. The appearance of ferritin in the peripheral blood of patients with acute hepatocellular disease is therefore attributed to a release of ferritin from disintegrating liver cells.

Marked ferritinemia was found in all of six patients with Hodgkin's disease involving the liver. This ferritinemia persisted over periods of several weeks and was not accompanied by an elevation in beta $_{1}$-globulin bound iron. No ferritin was found in sarcoidosis or carcinomatosis of the liver, nor in patients with Hodgkin's disease not involving the liver.

\section{ACKNOWLEDGMENT}

The authors are indebted to Drs. Mahlon H. Delp, Robert W. Weber, and Sloan J. Wilson for permission to study patients under their care.

\section{REFERENCES}

1. Matassarin, B. M., and Delp, M. H., The relation of serum iron to hepatocellular damage. Am. J. M. Sc., 1952, 224, 622.

2. Peterson, R. E., The serum iron in acute hepatitis. J. Lab. \& Clin. Med., 1952, 39, 225.

3. Kipping, H., and Schmoldt, H., Die Bedeutung des Eisens bei Lebererkrankungen. Deutsche Arch. Klin. Med., 1951, 198, 434.

4. Hemmler, G., Serumeisen und Leber. Klin. Wchnschr., 1939, 18, 1245.

5. Reissmann, K. R., Boley, J., Christianson, J. F., and Delp, M. H., The serum iron in experimental hepatocellular necrosis. J. Lab. \& Clin. Med., 1954, 43, 572.

6. Reissmann, K. R., Christianson, J. F., Boley, J. O., and Kittle, F. C., The relation of serum iron changes, hepatic function, and histologic findings in experimental hepatic injuries of various etiologies. Surgery, 1955, 37, 738.

7. Granick, S., Ferritin IV. Occurrence and immunological properties of ferritin. J. Biol. Chem., 1943, 149, 157.

8. Mazur, A., and Shorr, E., A quantitative immunochemical study of ferritin and its relation to the hepatic vasodepressor material. J. Biol. Chem., 1950, 182, 607.

9. Mazur, A., and Shorr, E., Hepatorenal factors in circulatory homeostasis. IX. The identification of the hepatic vasodepressor substance, VDM, with ferritin. J. Biol. Chem., 1948, 176, 771.

10. Shorr, E., Mazur, A., and Baez, S., Chemical and biological properties of the hepatorenal factors VEM and VDM (ferritin). Recent Progress in Hormone Research, 1955, 11, 453.

11. Scott, E. M., The determination of iron in tissues. Arch. Biochem., 1945, 6, 27.

12. Wong, S. Y., Colorimetric determination of iron and hemoglobin in blood. II. J. Biol. Chem., 1928, 77, 409.

13. Barkan, G., and Walker, B. S., Determination of serum iron and pseudohemoglobin iron with o-phenanthroline. J. Biol. Chem., 1940, 135, 37.

14. Mazur, A., Baez, S., and Shorr, E., The mechanism of iron release from ferritin as related to its biological properties. J. Biol. Chem., 1955, 213, 147.

15. Haley, T. J., Andem, M. R., Riley, R. F., and Williams, I., Identification of ferritin in blood of dogs subjected to radiation from an atomic detonation. Proc. Soc. Exper. Biol. \& Med., 1952, 79, 547.

16. Haley, T. J., Riley, R. F., Williams, I., and Andem, M. R., Presence and identity of vasotropic substances in blood of rats subjected to acute whole body roentgen ray irradiation. Am. J. Physiol., $1952,168,628$.

17. Baez, S., Mazur, A., and Shorr, E., Hepatorenal factors in circulatory homeostasis. $\mathrm{XX}$ : Antidiuretic action of hepatic vasodepressor, VDM (ferritin). Am. J. Physiol., 1952, 162, 198. 